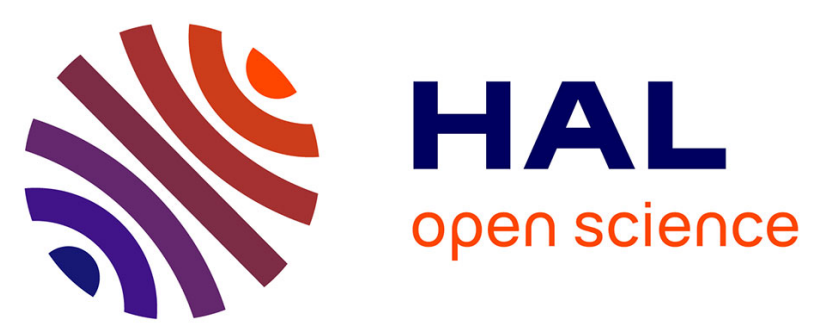

\title{
Unambiguous localization of titanium and iron cations in doped manganese hollandite nanowires
}

Isabel Gómez-Recio, Alberto Azor-Lafarga, M. Luisa Ruiz-González, Maria Hernando, Marina Parras, José Juan Calvino, María Teresa Fernández-Díaz, David Portehault, Clément Sanchez, José M González-Calbet

\section{To cite this version:}

Isabel Gómez-Recio, Alberto Azor-Lafarga, M. Luisa Ruiz-González, Maria Hernando, Marina Parras, et al.. Unambiguous localization of titanium and iron cations in doped manganese hollandite nanowires. Chemical Communications, 2020, 56 (35), pp.4812-4815. 10.1039/D0CC01888K . hal02923106

\section{HAL Id: hal-02923106 https: / hal.sorbonne-universite.fr/hal-02923106}

Submitted on 10 Nov 2020

HAL is a multi-disciplinary open access archive for the deposit and dissemination of scientific research documents, whether they are published or not. The documents may come from teaching and research institutions in France or abroad, or from public or private research centers.
L'archive ouverte pluridisciplinaire HAL, est destinée au dépôt et à la diffusion de documents scientifiques de niveau recherche, publiés ou non, émanant des établissements d'enseignement et de recherche français ou étrangers, des laboratoires publics ou privés. 


\section{Unambiguous localization of titanium and iron cations in doped manganese hollandite nanowires}

Received 00th January 20xx, Accepted 00th January 20xx

DOI: $10.1039 / \times 0 \times x 00000 x$

www.rsc.org/
Isabel Gómez-Recio ${ }^{\mathrm{a}, \mathrm{b}}$, Alberto Azor-Lafarga ${ }^{\mathrm{a}}$, M. Luisa Ruiz-González ${ }^{\mathrm{a}}$, María Hernando ${ }^{\mathrm{a}}$, Marina Parras $^{\mathrm{a}}$, José Juan Calvinoc ${ }^{c}$, María Teresa Fernández-Díaz ${ }^{\mathrm{d}}$, David Portehault ${ }^{\mathrm{b}}$, Clement Sanchez ${ }^{\mathrm{b}}$, and José M. González-Calbet ${ }^{\mathrm{a}, \mathrm{e}^{*}}$
New insights into the chemical and structural features of iron or titanium-doped $\mathrm{K}_{\mathrm{x}} \mathrm{MnO}_{2}$ hollandites are reported. Neutron diffraction and atomically resolved transmission electron microscopy elucidate the localization of the dopant cations that could be one of the key factors governing the functional activity of these nanomaterials.

Hollandite oxides, $\alpha-\mathrm{MnO}_{2}$, belong to an intriguing class of microporous manganese oxides that have attracted special attention due to their remarkable properties for energy storage, such as pseudocapacity in supercapacitors and electrocatalysis in rechargeable batteries ${ }^{1,2}$. These compounds also exhibit ion exchange $^{3}$ and magnetic properties ${ }^{4}, 5$. They are efficient materials for radioactive waste immobilization ${ }^{6}$ and for catalysis in different reactions ${ }^{7-10}$. This multifunctionality arises from the one-dimensional tunnel structure of hollandites, formed by dimeric chains of edge-sharing $\mathrm{MnO}_{6}$ octahedra oriented along the $c$ crystallographic axis. Each dimeric chain is connected to two others in the $a b$ plane by the octahedra corners, forming $2 \times 2$ and $1 \times 1$ tunnels along the $c$ axis (Figure 1 ). The $1 \times 1$ tunnels are usually empty while the $2 \times 2$ ones are partially occupied by large cations such as $\mathrm{K}^{+}$or $\mathrm{Ba}^{2+}$, which promote the partial reduction of $\mathrm{Mn}(\mathrm{IV})$ to $\mathrm{Mn}(\mathrm{III})$, and then the formation of a mixed $\mathrm{Mn}$ valence compound. The $2 \times 2$ channels are also usually partially filled with water molecules accompanying the cations. To tune and improve the numerous properties of hollandites, a lot of research has been devoted to design new pathways for controlling the particle size, morphology and for incorporating dopant cations ${ }^{10-12}$. This last approach has received special attention in catalysis ${ }^{9,13-18}$. Nevertheless, in spite of the large number of studies that prove properties improvement due to doping, the position of the foreign cation is only inferred by indirect methods ${ }^{13}, 19,20$. The present work focuses on tuning two synthetic pathways to allow easy and reproducible incorporation of $\mathrm{Ti}$ and Fe cations in hollandite nanowires, and then to thoroughly assess the presence and localization of dopant cations. Fe has been selected because this cation is known to enhance catalytic properties of hollandites ${ }^{18}, 20,21$.

\footnotetext{
a. Departamento de Química Inorgánica, Facultad de Químicas, Universidad Complutense, 28040-Madrid, Spain.

b. Sorbonne Université, CNRS, Collège de France, Laboratoire Chimie de la Matière Condensée de Paris (LCMCP), 4 Place Jussieu, F-75005 Paris, France.

c. Facultad de Ciencias, Universidad de Cádiz, Campus Rio San Pedro, Puerto Real, Spain.

d.Institut Laue-Langevin, 71 avenue des Martyrs, CS 20156, 38042 Grenoble cedex 9, France

e. Centro Nacional de Microscopía Electrónica, Universidad Complutense, 28040 Madrid, Spain.
}

Titanium, on the other side, has been selected because of its ability to form hollandite structures ${ }^{22}$. Titanium doping in manganese hollandites has not been reported yet.

Herein we have designed hollandite-type manganese oxides following two synthetic pathways (details in SI and Table SI 1). The first approach consists in a one-pot synthesis by the reaction between $\mathrm{Mn}\left(\mathrm{SO}_{4}\right)_{2}$ and $\mathrm{KMnO}_{4}$ in acidic aqueous medium ${ }^{23,24}$. Doped hollandite oxides were obtained by adding to the initial $\mathrm{Mn}\left(\mathrm{SO}_{4}\right)_{2}$ solution the foreign metal precursor, $\left(\mathrm{Fe}\left(\mathrm{NO}_{3}\right)_{3} \cdot 9 \mathrm{H}_{2} \mathrm{O}\right.$ or titanium(IV) bis(ammonium lactato) dihydroxide. The second approach is a two-steps route where layered birnessite manganese oxide is first formed by precipitation in basic aqueous medium at room temperature, and then transformed into hollandite by acidic hydrothermal treatment ${ }^{25}$. Doped birnessites are obtained again by addition of Fe and Ti precursors to the reaction medium.

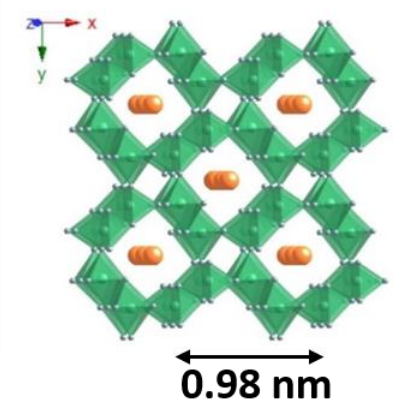

Figure 1. Crystal structure of hollandite oxide $\left(\mathrm{K}_{\mathrm{x}} \mathrm{MnO}_{2}\right)$. Color code: $\mathrm{K}$ orange, $\mathrm{Mn}$ green and $\mathrm{O}$ grey.

The incorporation of $\mathrm{Fe}$ and $\mathrm{Ti}$ in the materials was confirmed by cationic elemental analysis using electron microprobe analysis (EMPA) (Table SI 1). The formation of doped hollanditetype (S.G. $14 / \mathrm{m}$ ) single phases was supported by Le Bail analysis of the X-ray diffraction patterns (Figure 2a, Figure SI 1, Table SI 2). An increase in the cell parameters is observed upon doping (Table SI 4), in good agreement with the larger cationic radii of the dopants $\mathrm{Ti}^{4+}(0.61 \AA)$ and $\mathrm{Fe}^{3+}(0.65 \AA)$ compared to $\mathrm{Mn}^{4+}(0.53 \AA)^{26}$. Both EMPA and diffraction data show unambiguously that the foreign cations are hosted in the oxide's frameworks. For all compositions, a strong anisotropy is observed, as the $(002)$ peak $\left(\approx 65^{\circ}\right)$ is more narrow than other peaks, which suggests preferential growth of nanowires along the [001] direction 27 , as confirmed by TEM (Figure 2c-e). Diffraction peaks are also broadening (Table SI 3) with an increase of the dopant concentration, suggesting smaller particles or incorporation of larger strain. TEM (Figure 2c-e) 
confirms that the length of the nanowires decreases upon doping.

To get further insights into the presence and localization of eventual anionic vacancies and into the cationic distribution of

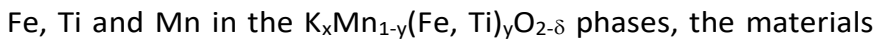
were analyzed by neutron diffraction (ND). Since materials obtained by both synthetic pathways are structurally and compositionally analog according to the results described above, ND was performed only on one-pot materials. In order to avoid incoherent scattering of adsorbed water molecules (Figure SI 2), the samples were partially dehydrated at $180{ }^{\circ} \mathrm{C}$ for $24 \mathrm{~h}^{28}$ (Figures SI 2 and SI 3). The ND data collected at room temperature were refined in the $14 / \mathrm{m}$ space group ${ }^{29}$. The atomic coordinates, thermal parameters and occupancy factors of atoms were refined. The Rietveld refinement patterns and difference plots for $\mathrm{K}_{0.11} \mathrm{MnO}_{2-\delta}, \quad \mathrm{K}_{0.11} \mathrm{Mn}_{0.95} \mathrm{Fe}_{0.05} \mathrm{O}_{2-\delta}$, $\mathrm{K}_{0.09} \mathrm{Mn}_{0.8} \mathrm{Fe}_{0.2} \mathrm{O}_{2-\delta}$, and $\mathrm{K}_{0.1} \mathrm{Mn}_{0.9} \mathrm{Ti}_{0.1} \mathrm{O}_{2-\delta}$ are shown in Figure $2 \mathrm{~b}$, Figure SI 3a, SI 3b and SI 3c, respectively. The refined structural parameters for all four hollandites are listed in SI-2 (Table SI 4). For the undoped sample, the value of the final isotropic atomic displacement parameter of potassium cation is much larger than those for manganese and oxygen. This yields instabilities during the refinement so that the potassium content had to be fixed according to the value obtained by elemental analysis
(Table SI 1). This behavior can be attributed to the easy-mobility of $\mathrm{K}^{+}$in the tunnel and to residual water molecules in the channels (Figure SI 4). The divergence between cell parameters values obtained by XRD and ND could be caused by the presence of a greater amount of water in the former. The $\mathrm{Mn}$-O distances (Table SI 5) show distorted $\mathrm{MO}_{6}$ octahedra in all hollandites, with three short $\mathrm{Mn}-\mathrm{O} 1$ distances and three long $\mathrm{Mn}-\mathrm{O} 2$ ones (Figure SI 5a). This feature corresponds to the displacement of the manganese cation from the octahedron center toward the three oxygen of the unshared edges to minimize $\mathrm{Mn}-\mathrm{Mn}$ repulsions between edge-sharing octahedra (Figure SI 5b). The average $\mathrm{Mn}-\mathrm{O}$ distances are in agreement with those observed in other $\mathrm{MnO}_{2}$ phases (pyrolusite at $1.89 \AA^{30}$ and ramsdellite at $1.90 \AA)^{31}$ The composition of the undoped phase is $\mathrm{K}_{0.11} \mathrm{MnO}_{1.958(1)}$ according to EMPA and ND. The occupancy factors of the oxygen atoms reveal anionic vacancies mostly on the $\mathrm{O} 2$ position (Table $\mathrm{SI} 4$ ), which corresponds to $\mathrm{O}^{2-}$ anions located in the connection between adjacent dimers (Figure SI 5c). This conclusion is in agreement with the hypothesis formulated by $\mathrm{Wu}$ and co-workers ${ }^{32}$. Importantly, we report herein the first experimental localization of oxygen vacancies in manganese hollandites.

The presence of $\mathrm{Ti}$ and $\mathrm{Fe}$ in the octahedral sites of doped hollandites does not significantly modify the Mn-O distances
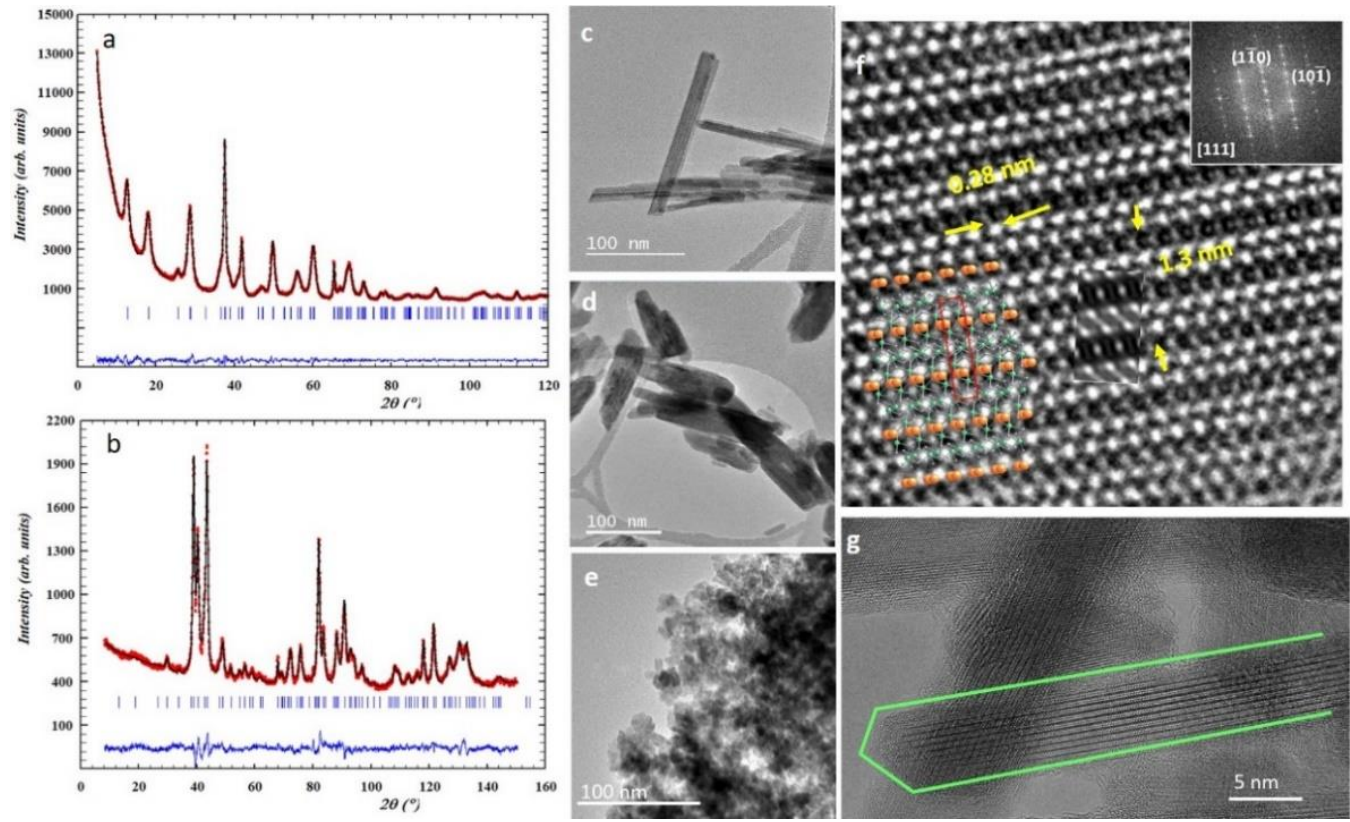

Figure 2. (a) Le Bail analysis of X-ray diffraction patterns and (b) Rietveld refined powder neutron diffraction pattern of the undoped hollandite obtained by one-pot synthesis. Low magnification TEM images of (c) $\mathrm{K}_{0.12} \mathrm{MnO}_{\delta} ;$ (d) $\mathrm{K}_{0.12} \mathrm{Mn}_{0.95} \mathrm{Fe}_{0.05} \mathrm{O}_{2 . \delta}$, and (e) $\mathrm{K}_{0.09} \mathrm{Mn}_{0.8} \mathrm{Fe}_{0.2} \mathrm{O}_{2-\delta}$ (nominal composition). (f, g) HRTEM images at different magnifications for $\mathrm{K}_{0.12} \mathrm{MnO}_{\delta}$. $\mathrm{FFT}$, calculated image $(\Delta \mathrm{t}=8 \mathrm{~nm}, \Delta \mathrm{f}=-20 \mathrm{~nm})$ and schematic structural model are inserted in (f). 
compared to the undoped $\mathrm{K}_{0.11} \mathrm{MnO}_{1.958(1)}($ Table SI 5). For the Fe-doped hollandites, $\mathrm{K}_{x} \mathrm{Mn}_{1-y} \mathrm{Fe}_{y} \mathrm{O}_{2-\delta}$, ( $y=0.05$ and 0.2 ) the octahedral site was constrained to be fully occupied but no constraint was imposed on the $\mathrm{Mn}$ :Fe ratio. The distribution of $\mathrm{Mn}$ and Fe among octahedra is summarized in Table SI 4. The refinement shows again the presence of anionic vacancies. The full compositions obtained were $\mathrm{K}_{0.11} \mathrm{Mn}_{0.946(2)} \mathrm{Fe}_{0.054(2)} \mathrm{O}_{1.899(14)}$ and $\mathrm{K}_{0.09} \mathrm{Mn}_{0.844(2)} \mathrm{Fe}_{0.156(2)} \mathrm{O}_{1.904(17)}$. For $\mathrm{K}_{0.1} \mathrm{Mn}_{0.9} \mathrm{Ti}_{0.1} \mathrm{O}_{2-\delta}$, the cationic composition could not be refined due to the very close scattering lengths of $\mathrm{Mn}(-3.73 \mathrm{fm})$ and $\mathrm{Ti}(-3.438 \mathrm{fm})^{33}$. Nevertheless, the refinement clearly shows that the $\mathrm{Ti}$ atoms cannot be located in the structure channels.

A representative HRTEM image (Table SI 6), its corresponding FFT and calculated image for the undoped sample (Figure 2f-g) are in good agreement with the hollandite unit cell. HRTEM images for other orientations and compositions are provided in Figure SI 6 and Figure SI 7.

In order to unambiguously solve the localization of the dopant cations and their electronic properties, an atomically resolved STEM spectrum-image study (SI) has been performed, despite the high instability of the samples under the focused electron beam. Characteristic spectrum-images studies of iron-doped samples are shown in Figure 3. Alternating atomic columns with large contrast are observed by High Angle Annular Dark Field (HAADF) imaging (Figure 3a, b), corresponding to Mn/dopant columns, in agreement with the expected structure (inserted schematic model) and structural refinements. $K$ is not detected by HAADF due to its low content as well as to the presence of much heavier neighboring Mn cations. Nonetheless, the sum EELS spectrum (Figure $3 c$ ) shows characteristic edges of all the elements, $K-L_{2,3}, \quad O-K, \quad M n-L_{2,3}$ and $F e-L_{2,3}$, while the corresponding chemical maps confirm their distribution according to the crystal structure. Fe and $\mathrm{Mn}$ are collocated, so that $\mathrm{Fe}$ predominantly substitutes $\mathrm{Mn}$, in agreement with structural refinement.

The low signal-to-noise ratio observed for Fe is due to its low concentration as well as to the low acquisition time (discussion SI 4) required in order to avoid sample degradation. Similar results are obtained for $\mathrm{Ti}$ doped samples (Figure $\mathrm{SI} 8$ ). The mean oxidation states of $\mathrm{Mn}, \mathrm{Fe}$ and $\mathrm{Ti}$ were evaluated from EELS spectra recorded along lines to have enough statistic and avoid sample damage (discussion SI 5). Both doped and undoped samples exhibit a $\mathrm{Mn}-\mathrm{L}_{2,3}$ edge typical of coexisting $\mathrm{Mn}^{3+}$ and $\mathrm{Mn}^{4+}$ oxidation states (Figure $3 \mathrm{i}$ and discussion $\mathrm{SI} 5$ ) when compared with $\mathrm{Mn}^{2+}, \mathrm{Mn}^{3+}$ and $\mathrm{Mn}^{4+}$ standards with a good agreement between the relative intensity ratio of the $\mathrm{Mn}$ $\mathrm{L}_{2}$ and $\mathrm{Mn}-\mathrm{L}_{3}$ white lines (discussion SI 5). Likewise, the oxidation states of $\mathrm{Fe}$ and $\mathrm{Ti}$ in the doped samples are +3 and +4 respectively. These values are in good agreement with the chemical composition obtained by chemical analysis and neutron diffraction.

\section{Conclusions}

In summary, nanoparticles of titanium and iron doped hollandites have been obtained according to two synthetic pathways. In these materials, dopant metal ions are hosted in the manganese lattice, as evidenced by neutron diffraction and atomically resolved transmission electron microscopy. We report herein i) the first titanium doping of manganese hollandite and ii) the first experimental atom-scale observation providing unambiguous information on dopant and oxygen vacancies localization in manganese hollandites. This knowledge could be a fundamental key to understand and design the functional behavior of these materials.
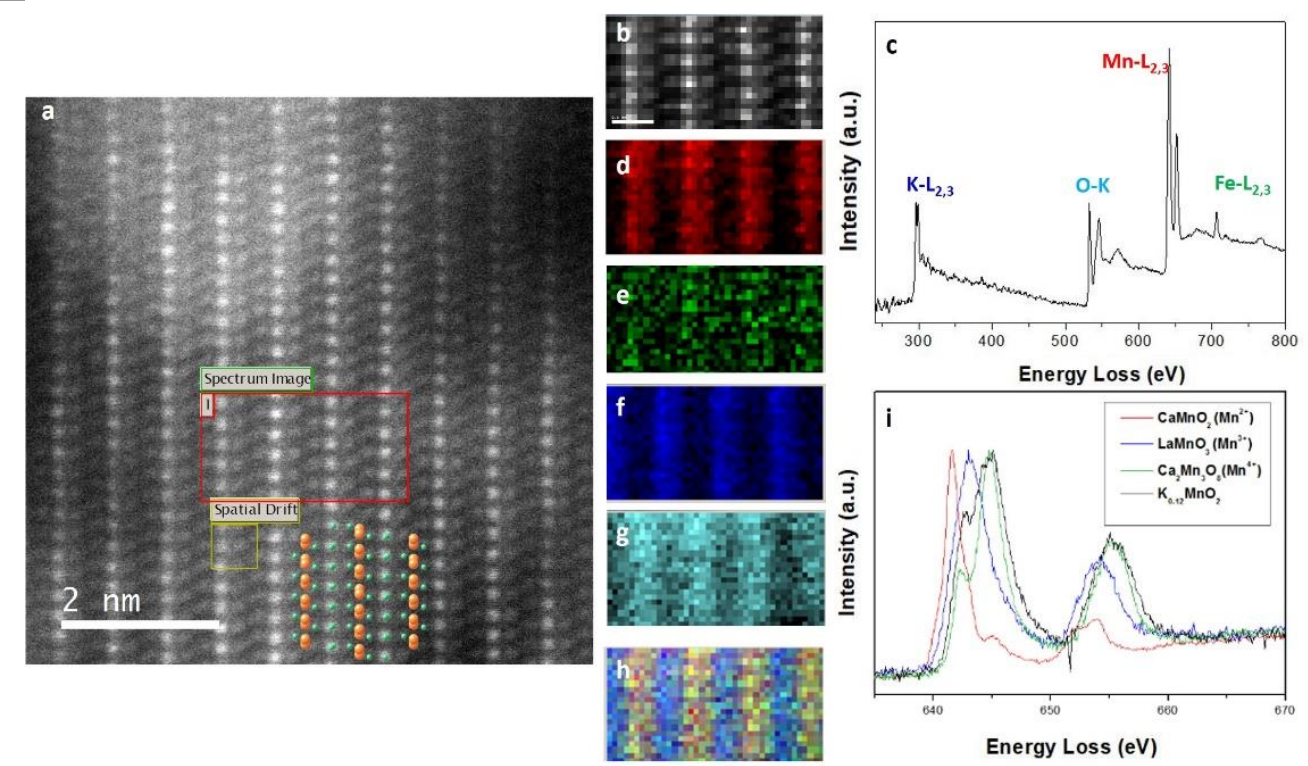

Figure 3. STEM-EELS study corresponding to Fe-doped hollandite. (a) HAADF images along the [111] zone axis, indicating the area where the spectrum image was performed; a schematic representation of the structure is also included. (b) HAADF image simultaneously recorded with the spectra. (c) Sum spectrum showing the edge of all the elements present. ( $\mathrm{d}-\mathrm{g}$ ) Chemical maps obtained from the different signals ( $\mathrm{Mn}$ red, $\mathrm{K}$ blue, Fe green, $\mathrm{O}$ soft blue). (h) Combined map showing all the elements. (i) Representative EELS spectra showing the $\mathrm{Mn}-\mathrm{L}_{2,3}$ signal for an undoped hollandite in comparison with references of $\mathrm{Mn}^{4+}, \mathrm{Mn}^{3+}$ and $\mathrm{Mn}^{2}$. 


\section{Conflicts of interest}

There are no conflicts to declare

\section{Notes and references}

1. Y. Yuan, C. Zhan, K. He, H. Chen, W. Yao, S. Sharifi-Asl, B. Song, Z. Yang, A. Nie, X. Luo, H. Wang, S. M. Wood, K. Amine, M. S. Islam, J. Lu and R. Shahbazian-Yassar, Nature Communications, 2016, 7, 13374.

2. F. Xu, L. Wu, Q. Meng, M. Kaltak, J. Huang, J. L. Durham, M. Fernandez-Serra, L. Sun, A. C. Marschilok, E. S. Takeuchi, K. J. Takeuchi, M. S. Hybertsen and Y. Zhu, Nature Communications, 2017, 8, 15400.

3. Q. Feng, H. Kanoh, Y. Miyai and K. Ooi, Chemistry of Materials, 1995, 7, 148-153.

4. J. Luo, H. T. Zhu, J. K. Liang, G. H. Rao, J. B. Li and Z. M. Du, The Journal of Physical Chemistry C, 2010, 114, 87828786.

5. J. B. Yang, X. D. Zhou, W. J. James, S. K. Malik and C. S. Wang, Applied Physics Letters, 2004, 85, 3160-3162.

6. A. Dyer, M. Pillinger, J. Newton, R. Harjula, T. Möller and S. Amin, Chemistry of Materials, 2000, 12, 3798-3804.

7. A. Davó-Quiñonero, D. Lozano-Castelló and A. BuenoLópez, Applied Catalysis B: Environmental, 2017, 217, 459465.

8. M. Özacar, A. S. Poyraz, H. C. Genuino, C.-H. Kuo, Y. Meng and S. L. Suib, Applied Catalysis A: General, 2013, 462, 6474.

9. L. Sun, Q. Cao, B. Hu, J. Li, J. Hao, G. Jing and X. Tang, Applied Catalysis A: General, 2011, 393, 323-330.

10. F. Cheng, Y. Su, J. Liang, Z. Tao and J. Chen, Chemistry of Materials, 2010, 22, 898-905.

11. L. Pahalagedara, D. A. Kriz, N. Wasalathanthri, C. Weerakkody, Y. Meng, S. Dissanayake, M. Pahalagedara, Z. Luo, S. L. Suib, P. Nandi and R. J. Meyer, Applied Catalysis B: Environmental, 2017, 204, 411-420.

12. D. Portehault, S. Cassaignon, E. Baudrin and J.-P. Jolivet, Chemistry of Materials, 2007, 19, 5410-5417.

13. L. Zhang, J. Tu, L. Lyu and C. Hu, Applied Catalysis B: Environmental, 2016, 181, 561-569.

14. H. C. Genuino, M. S. Seraji, Y. Meng, D. Valencia and S. L. Suib, Applied Catalysis B: Environmental, 2015, 163, 361369.

15. H. Huang, Y. Meng, A. Labonte, A. Dobley and S. L. Suib, The Journal of Physical Chemistry C, 2013, 117, 2535225359.

16. J. Huang, A. S. Poyraz, K. J. Takeuchi, E. S. Takeuchi and A. C. Marschilok, Chemical Communications, 2016, 52, 40884091.

17. K. Chung-Hao, L. Weikun, P. Lakshitha, E. S. A. M., K. David, G. Nina, G. Curtis, R. Thorsten, S. S. L. and H. Jie, Angewandte Chemie, 2015, 127, 2375-2380.

18. C. M. Vasconcellos, M. L. A. Gonçalves, M. M. Pereira and N. M. F. Carvalho, Applied Catalysis A: General, 2015, 498, 69-75.

19. C. K. King'ondu, N. Opembe, C.-h. Chen, K. Ngala, H. Huang, A. Iyer, H. F. Garcés and S. L. Suib, Advanced Functional Materials, 2011, 21, 312-323.
20. S. Said and M. Riad, Solid State Sciences, 2019, 94, 145154.

21. E. W. McFarland and H. Metiu, Chemical Reviews, 2013, 113, 4391-4427.

22. K. Noami, Y. Muraoka, T. Wakita, M. Hirai, Y. Kato, T. Muro, Y. Tamenori and T. Yokoya, Journal of Applied Physics, 2010, 107, 073910.

23. Y. Li, Z. Fan, J. Shi, Z. Liu, J. Zhou and W. Shangguan, Catalysis Today, 2015, 256, 178-185.

24. Q. Feng, H. Kanoh and K. Ooi, Journal of Materials Chemistry, 1999, 9, 319-333.

25. S. Ching, P. F. Driscoll, K. S. Kieltyka, M. R. Marvel and S. L. Suib, Chemical Communications, 2001, 2486-2487.

26. R. D. Shannon, Acta Crystallogr., Sect. A: Cryst. Phys., Diffr., Theor. Gen. Crystallogr., 1976, A32, 751.

27. T. Barudzija, V. Kusigerski, N. Cvjeticanin, S. Šorgić, M. Perovic and M. Mitrić, Journal of Alloys and Compounds, 2016, 665, 261-270.

28. B. Ouladdiaf, J. Rodríguez-Carvajal, C. Goutaudier, S. Ouladdiaf, B. Grosgogeat, N. Pradelle and P. Colon, Materials Research Express, 2015, 2, 025401.

29. J. Vicat, E. Fanchon, P. Strobel and D. Tran Qui, Acta Crystallographica Section B, 1986, 42, 162-167.

30. A. Bolzan, C. Fong, B. Kennedy and C. Howard, Australian Journal of Chemistry, 1993, 46, 939-944.

31. J. E. Post and P. J. Heaney, American Mineralogist, 2004, 89, 969-975.

32. L. Wu, F. Xu, Y. Zhu, A. B. Brady, J. Huang, J. L. Durham, E. Dooryhee, A. C. Marschilok, E. S. Takeuchi and K. J. Takeuchi, ACS Nano, 2015, 9, 8430-8439.

33. V. F. Sears, Neutron News, 1992, 3, 26-37. 